\title{
Abortion from an Islamic Perspective: Permission and Prohibition Positions
}

\author{
Alqahtani Jawhrah Mohammed \\ King Saud University, School of Nursing, Riyadh 11451, Saudi Arabia \\ Corresponding author: Alqahtani Jawhrah Mohammed; jawhrah.alqahtani@mymail.barry.edu.
}

Received 05 June 2020;

Accepted 24 June 2020;

Published 03 July 2020

\begin{abstract}
Abortion is a common controversial ethical issue among humanists, feminists, liberals, and religious groups worldwide. Many countries permit induced abortion, or the deliberate termination of pregnancy, for various reasons e.g., as a means of contraception, as part of a woman's right to autonomy, or as part of a woman's right to determine the number of children she will bear. Even in Islamic countries, which hold strong religious laws and beliefs, it has been announced that abortion may be permissible before or after the period of "ensoulment" in certain circumstances and on medical grounds, so as to safeguard women from serious problems that might put their lives at risk. However, some religious groups do not support abortion. Therefore, it is critical to explore Islam's position on the prohibition or allowance of induced abortion.
\end{abstract}

Keywords: Induced abortion, Islam, Pregnancy.

\section{Background}

Abortion is subject to intense debates in many parts of the world, which has ethical, religious, legal, cultural, and psychosocial consequences ${ }^{[12]}$. Though abortion has been practiced throughout history, it encompasses crucial issues of right and wrong, life and death, and human relationships ${ }^{[11]}$. The World Health Organization (WHO) (2012) defines abortion as the expulsion of an embryo (fetus), weighing 500 grams or less, from its mother's womb ${ }^{[22]}$. As a broader concept, abortion can be classified into two main types: spontaneous and induced abortion ${ }^{[15]}$. Spontaneous abortion, known as miscarriage, is the termination of a pregnancy without any external interventions; the pregnant woman has no intention to abort the fetus ${ }^{[12,15]}$. This type of involuntary abortion is commonly caused by medical problems in the expectant mother or by a defect in the embryo ${ }^{[15]}$. On the other hand, induced abortion, known as intentional abortion, is the abnormal termination of unwanted pregnancy, resulting in the death of the fetus ${ }^{[12]}$.

Induced abortion is supported worldwide and is used legally in many Western countries as a means of birth control and for the purpose of saving the existing human life of the mother ${ }^{[18,19]}$. The purpose of legalizing this procedure is to prevent pregnant women from being involved in unsafe abortions, which can place them at risk of maternal morbidity and mortality ${ }^{[19,22]}$. Nevertheless, some Muslim countries have their own positions regarding the prohibition or legalization of abortion ${ }^{[9]}$. In the Muslim world, induced abortion creates an ethical dilemma and tension among religious scholars ${ }^{[7,9]}$. This paper, therefore, focuses on the issue of induced abortion in Islamic countries, discussing it from two perspectives and providing the author's opinion.

\section{Purpose}

The purpose of this article is to investigate the issue of induced abortion from two Islamic perspectives: for and against, supported with evidence. Two ethical theories that explaining the opposing positions are discussed. It concludes with the author's opinion in regards to this bioethical issue.

\section{Material and Method}

The following key terms were used to search for articles related to this topic: abortion, Islam, pregnancy, termination, life right, fetus, and bioethics. Several databases and advanced search options were used: peer-reviewed, research article, English language, and without any time limit. A total of 23 resources most relevant to the topic of induced abortion from an Islamic perspective were included in this review.

\section{Results and Discussion}

\section{Abortion from the Islamic Ethical Positions}

In Muslim countries, ongoing controversies exist over moral, ethical, legal, and religious problems, including abortion ${ }^{[14]}$. For Muslims, the Holy Qur'an and Sunnah are the primary authoritative sources of Islamic law, "Shariah." They are used to direct Muslim's lives and to answer any concerns they may have ${ }^{[15]}$. Since the Holy Qur'an has no texts on abortion, the Sunnah, as the second guiding source which is based on the traditions of the Prophet Mohammad (peace be upon him) is often relied on by religious scholars when constructing opinions and issuing verdicts, "Fatwa," concerning abortion ${ }^{[15]}$. However, within these 
communities, there is a substantial diversity of opinions on bioethical subjects. This diversity between Muslim countries stems from the various sects, schools of jurisprudence, and levels of religious observance within Islam, along with differences in social and cultural backgrounds ${ }^{[7]}$.

Under Islamic law, the general rule is that abortion is allowed when the life of the mother is threatened; otherwise, it is prohibited ${ }^{[9]}$. Abortion, called Al-ijhadh in Arabic, is permitted in cases of rape; fetal impairment, e.g., "abnormality, genetic disorders"; and risk to the woman's life and physical and mental health ${ }^{[14]}$. Some conservative jurists in Muslim-majority countries argue that abortion is ethically unacceptable and morally wrong on the grounds that it takes the life of an innocent human "fetus" [2,4]. However, most religious groups stand against this position, insisting that, according to Islam, the mother has priority to be protected and saved when there is a medical indication that the fetus is threatening the mother's health and life. Indeed, abortion should be considered necessary, without violating the fetus's right to live ${ }^{[2,4]}$.

\section{First Position: Permission}

Islamic positions on abortion vary, depending on the circumstances of the pregnancy and the stage of gestational development ${ }^{[9]}$. In 1990, the decision to permit induced abortion was officially passed under a number of conditions, from Islamic jurists and through a legal and religious "Fatwa," during the Council of all Islamic Jurists in Makkah, Saudi Arabia ${ }^{[8]}$. The International Islamic Fiqh (Islamic Jurisprudence) Council, which is the central Islamic Sunni institution of the Muslim World League, has also formulated a religious edict for resolving abortion issues among Muslims ${ }^{[21]}$. According to this institute, abortion is permissible, both before and after ensoulment of the fetus, if the mother's life is at risk and a malformation of the fetus is incurable.

In 2011, the Standing Committee for Scientific Research and for Issuing Edicts, Preaching, and Guidance of Saudi Arabia issued an updated edict, legalizing abortion in particular circumstances, as this dilemma is vital to humanity ${ }^{[16,21]}$. According to this legal and religious edict, the procedure for terminating pregnancy, in general, must occur before 120 days have elapsed since conception. (The spirit is believed to be breathed into the fetus at approximately this point.) Therefore, after ensoulment at 120 days (or 19 weeks' gestation), jurists have agreed that abortion is prohibited, except in cases of extreme necessity when continuation of the pregnancy is a severe threat to the mother's life ${ }^{[14]}$. Abortion of a malformed fetus is permissible at any time if the pregnancy is sure to pose a risk to the mother's life ${ }^{[16]}$. Additionally, when the fetus is physically deformed, abortion at any stage of the pregnancy is justified on the basis of medical necessity and to preserve the woman's physical and psychological health. Abortion may also be performed for women suffering from physical injury and/or severe mental distress due to the pregnancy that is, in cases when healthcare teams believe the medical condition may harm the mother's life. In instances of rape, abortion may be used to terminate a pregnancy resulting from unlawful and unwilling sexual violence, at any time, on the basis of established necessity, to keep the victims and their families from sustaining any further harm. More importantly, abortion, in all the above cases, shall not be permissible without a medical report of the mother's and fetus's conditions from three competent and trustworthy physicians nor without the consent of both parents or of the pregnant woman alone ${ }^{[8]}$.

These permissible forms of abortion are based on revelations derived from the Holy Quran and Sunnah, supported by a number of Fatwa. Allowances are evident in the following verses of the Holy Qur'an: "A mother should not be made to suffer because of her child"; "...No soul shall have imposed upon it a duty but to the extent of its capacity; neither shall a mother be made to suffer harm on account of her child...." [13, Surah Al-Baqarah 2:233]; "He has chosen you and not placed upon you a religion that causes you difficulty" [13, Al-Hajj 22:7813].

Concerning rape cases, Sheikh Saeed Muhammad Tantawi, the Grand Sheikh of Al-Azhar Sharrif, which is the highest Islamic council in Egypt, issued a Fatwa in 2007 allowing unmarried women, who are victims of rape, to receive abortions, even after 120 days of conception, as there is an immense need to provide immediate solutions to the victims and their families in such situations. He believes that abortion, in this case, would not contradict Islamic laws and principles. Sheikh Tantawi's ruling is based on the following Qur'anic provisions: “...No soul shall have imposed upon it a duty but to the extent of its capacity; neither shall a mother be made to suffer harm on account of her child...." [13, Surah Al-Baqarah 2:233]; "He who suspects that the testator has committed an error or injustice and then brings about a settlement among the parties concerned incurs no sin. Surely Allah is Much-Forgiving, Most Compassionate" [20, Surah Al-Baqarah $2: 182]$. In this position, the Holy Qur' an and Fatwa recognize equal rights to life for the mother and the fetus, as both have the same dignity and deserve to be respected and treated as equals.

In this position, it is evident that the Holy Qur'an upholds the principle of life but does not explicitly talk about the rights to abortion unless a situation becomes dangerous (i.e., threatening the mother's life) or grave (i.e., cases of rape or fetal malformation). Parallel to this, most Islamic jurists approach this subject to protect the rights of humanity and equality, which, as stated in the Holy Qur'an, are to live and thrive. Islamic jurists have come to an agreement after long periods of studying this matter; abortion after ensoulment is forbidden unless it falls under a necessitated condition and reason. Non-allowance or prohibitions of abortion, in rape cases, may expose the raped women and unmarried girls and their families, in Muslim communities, to further social discrimination and unnecessary grief, shame, and sorrow, in addition to the physical and emotional trauma. Hence, the victims in such cases are given this dispensation out of necessity; rape justifies the need for abortion. Under this religious and legal position, it is readily evident that Muslim mothers and pregnant women are supported with scientific facts, clinical documents, and medical examinations, which helps them be informed about the abortion and its consequences. Concurrently, women are empowered to make an appropriate judgment and decide whether to proceed with abortion. This, in turn, gives all women the freedom to make ethical and moral decisions and the autonomy to protect their fetus's and their own wellbeing or to undergo a safe and legal abortion if so desired without contradicting Islamic bioethical principles.

\section{Second Position: Prohibition}

On the other hand, some conservative jurists do not encourage or permit induced abortion; instead, they link the process of termination to killing a human being (fetus), who has not yet fully developed ${ }^{[3]}$. The opposition to abortion is based on the following Islamic belief: all forms of life-taking are prohibited, including abortion and suicide, because life is strongly believed to be priceless and sacred. In Islam, the fetus's life or the birth of a baby is generally believed to be a gift from God, "Allah," which must be protected and accepted with gratitude; as such, even the fetus, who has not yet fully developed, is entitled to protection ${ }^{[5]}$. 
Abortion is also contrary to the core principles of Islam and its customs of birth. Some argue that abortion is forbidden after 120 days of conception ${ }^{[5]}$. That is because the spirit is breathed into the fetus, a process which is believed to take place at approximately 120 days after conception; thus, the fetus's right to life begins once ensoulment occurs ${ }^{[5]}$. After 120 days, the prohibition of abortion becomes more serious due to the belief that the fetus has been given a soul and is completely formed. It is generally believed that Allah's anger and punishment await each individual who has intentionally and voluntarily caused, encouraged, or conducted abortion. Most importantly, Islamic principles recognize the value of all human life; hence, the fetus's right to life is fully protected and respected ${ }^{[5]}$.

The arguments of those against abortion are based on the following Qur'anic verse: “...And do not kill the soul which Allah has forbidden, except by right. And whoever is killed unjustly We have given his heir authority, but let him not exceed limits in [the matter of] taking life. Indeed, he has been supported [by the law]" [1, Quran 17:33]. In the words of contemporary scholar Sheikh Yusuf Al-Qaradawi (2013), "While Islam permits preventing pregnancy for valid reasons, it does not allow doing violence to it once it occurs ${ }^{[6]}$."

In this position, it is apparent that conservative jurists reject abortion because it ends the life of an innocent human, who is in the process of development. As Islam upholds the sanctity of life, allowing this biological human being to develop and be born alive is a direct manifestation of respect for rights to life and human dignity. It is considered neither ethical nor moral to solely give women the rights to save their own lives, especially when abortion is related to another life that of the fetus. This act of terminating the fetus's life is a crime and violence against this human being; abortion should not be justified or be considered right because of its benefits in saving the mother's life. The Holy Qur'an's perspective grants each human being, even at the earliest stages of development, the right to live and to be respected, even prior to birth. Hence, abortion is considered morally offensive and a violation of the fetus's right to live.

\section{Ethical Theories}

\section{Deontological, and Teleological Theories}

Two ethical theories the deontological and teleological theories are applicable for explaining the two opposing positions concerning abortion. Deontological ethics are concerned with determining the wrongness or rightness of human actions; teleological ethics are more concerned with acknowledging the badness or goodness of human actions ${ }^{[10]}$. The teleological theory coincides with the position of the first group supporting abortion, while Kant's deontological theory aligns with the second group firmly against abortion.

Teleological theory, also known as consequentialist ethics, has to do with an individual and his or her goals; the individual makes decisions to cause the best possible outcome ${ }^{[10]}$. Teleological theory is based on connecting the consequences of human actions to moral concepts, including moral or immoral, right or wrong, good or bad ${ }^{[10]}$. It also focuses on balancing the "moral concepts" of good over bad, or right over wrong, in which all human actions should cause the best outcome and the least amount of bad ${ }^{[10]}$. In teleological ethics, what is important is what happens as a consequence of human actions. Thus, actions are ultimately good or bad depending on the nature of their consequences ${ }^{[10]}$. From a teleological standpoint, in any decision (e.g., abortion), there is an endless number of consequences or outcomes (e.g., emotional distress, risks, death of the fetus) and as many contributory factors (e.g., medical, social, cultural) come into play; thus, it is not the action itself (abortion) that causes the positive outcome, but more the intention (mother) to act.

Kant's deontology, also called ethics of duty, is more concerned with what a person does rather than with the consequences of his or her actions ${ }^{[17]}$. Deontology is grounded on universal moral rules and principles, in which respect for people and their autonomy is fundamental ${ }^{[17]}$. Deontological ethics emphasizes that the morality of an action should be based on whether that action itself is right or wrong under several moral rules rather than based on the consequences of the action ${ }^{[10]}$. It primarily focuses on duty-based ethics, which entails respecting human autonomy, telling the truth, and doing no harm ${ }^{[23]}$. For Kant, each human must be respected and treated as a purpose in itself: "Act in such a way, as to always treat humanity, in its own person or in the person of another, always at the same time as purpose and never simply as a means" [17, p. 42]. Within deontological ethics, unwanted and unlawful pregnancy does not justify abortion for any woman. Abortion is morally wrong, regardless of the good produced and the outcomes to which it may lead, such as saving the mother's life and protecting her physical and mental health. Kant's theory places the core value on the life of the fetus, which drives the human (that is, the mother's) behaviors to not abort, to do good, to do her duty, to adhere to moral standards, and to provide equal treatment to the unborn fetus.

\section{Conclusion}

Regarding abortion, there are diverse views from both groups, yet they agree upon one fundamental fact: abortion is the act of terminating or expulsing a fetus's life before it is born. Both positions also agree that Islamic religion and abortion laws value the lives of the mother and the fetus. Based on this elucidation, abortion, for the purpose of saving the mother's life and health, is permitted and justifiable, as stated in the first position. This ensures the woman's right to live. The objection to abortion in the second position comes from the beliefs that abortion is morally wrong and that the fetus has the same right to live as the mother. Therefore, supporting abortion to save the mother, at the expense of the unborn fetus, is an immoral and inhumane act.

Based on the interpretations from both positions, this author believes that induced abortion is a serious bioethical issue because terminating pregnancy is directly connected with the right to life. However, such abortions should be mainly allowed for overriding medical reasons and social necessities, no matter the stage of pregnancy, as the Holy Qur'an does not specify when ensoulment takes place. Abortion, therefore, should not be equated with the intentional act of killing a human being.

\section{References}

[1] Abdullah Yusuf Ali. Quran Translation. Quran Yusuf Ali. https://quranyusufali.com

[2] Abdun Nasir, M. (2011). The Majelis Ulama's Fatwā on abortion in contemporary Indonesia. The Muslim World, 101(1),

33-52. https://onlinelibrary.wiley.com/doi/abs/10.1111/j.14781913.2010.01341.x

[3] Al Bar, M., Al Ijhadh, M. (1985). The problem of abortion. Saudi Publishing House. https://heinonline.org/HOL/LandingPage?handle=hein.jo urnals/mlv23\&div $=12 \&$ id $=\&$ page $=$ 
[4] Al-Hibri, A. Y. (1993). Family Planning and Islamic Jurisprudence.

https://scholarship.richmond.edu/cgi/viewcontent.cgi?ref erer=https://scholar.google.com/scholar

[5] Alkali, A. U., Binti Mohd, A., Hak, N. A., \& Soh, R. C. (2015). Abortion: An Infringement of the Foetus' Right to Life in Islamic Law. IIUM Law Journal, 23(1). https://journals.iium.edu.my/iiumlj/index.php/iiumlj/artic le/view/158

[6] Al-Qaradawi, Y. (2013). The lawful and the prohibited in Islam: (Al-halal wal haram fi al-Islam) في وال حرام الـ حلال lllor The Others. https://books.google.com/books?hl=en\&lr=\&id=iXCNA QAAQBAJ\&oi=fnd\&pg=PR $1 \& d q=$ Al-

Qaradawi+Yusuf.,+The+Lawful+and+Prohibited+in+Isla $\mathrm{m},+\&$ ots $=$ U $5 \mathrm{MXw}-$

$1 \mathrm{~KB} 1 \&$ sig $=$ XthN0gW1U1tsGGQ4d3bhI0N2UQo\#v=on epage \&q=Al-

Qaradawi\%20Yusuf.\%2C\%20The\%20Lawful\%20and\% 20Prohibited $\% 20 \mathrm{in} \% 20$ Islam $\% 2 \mathrm{C} \& \mathrm{f}=$ false

[7] Asman, O. (2004). Abortion in Islamic countries Legal and religious aspects. Medicine and Law, 23, 73. https://heinonline.org/HOL/LandingPage?handle=hein.jo urnals/

[8] Bagheri, A., Afshar, L., Shahin, M. A., Zawawi, M., Albar, M., \& Aksoy, S. (2011). Abortion in different Islamic jurisprudence: Case and commentaries. Asian Bioethics Review, 3(4). https://s3.amazonaws.com/academia.edu.documents/327 03331/Abortion_in_Different_Islamic_Jurisprudence.pdf ?

[9] Dayan, F., Sheraz, M. M., Mahmood, M. R., Al Mahmood, A. K., \& Islam, S. (2020). A medico-legal perspective on the termination of pregnancies resulting from wartime-rape. Bangladesh Journal of Medical Science, 19(3), 372-385. https://www.banglajol.info/index.php/BJMS/article/view/ 45852

[10] Frankena, W. K. (1963). Ethics. Prentice-Hall. https://philpapers.org/rec/FRAE-5

[11] Gilbert, I., \& Sewpaul, V. (2015). Challenging dominant discourses on abortion from a radical feminist standpoint. Affilia, $30(1)$, 83-95. https://journals.sagepub.com/doi/abs/10.1177/088610991 4549232?casa_token=egEMAvyYegAAAAA:vYtw_LcVIB4RoBAI6eBUsryS6UCMlig Qol7WMgFoIPcFyKvfG1lveP031AoiXJFjntPF_zZ08_s

[12] Grisanti, M. A. (2000). The abortion dilemma. The Master's Seminary Journal (MSJ), 11(2), 169-190. https://www.tms.edu/m/tmsj11i.pdf

[13] Glorious Qur'an. Amazon. https://www.amazon.com/Glorious-Quran-MuhammadM-Pickthall/dp/1879402513

[14] Hessini, L. (2007). Abortion and Islam: Policies and practice in the Middle East and North Africa. Reproductive Health Matters, 15(29), 75-84.
https://www.tandfonline.com/doi/abs/10.1016/S09688080(06)29279-6

[15] Kamali, M. H. (1991). Principles of Islamic jurisprudence. The Islamic Text Society. http://www.targheeb.com/phocadownload/Fiqh/ISLAMI C\%20LAW\%20HISHAM\%20KAMALI.pdf

[16] Standing Committee for Scientific Research and Issuing Edicts. (2011). Preaching and Guidance in Saudi Arabia. Proceedings of the Standing Committee for Scientific Research and Issuing Edicts. Council of the Muslim World League. https://www.themwl.org/ar/allconferences

[17] Kant, Immanuel (1972). The critique of practical reason. Scientific Publishers House. https://www.britannica.com/biography/Immanuel-Kant

[18] Schwartz, R. A. (1972). The social effects of legal abortion. American Journal of Public Health, 62(10), 1331-1335.

https://ajph.aphapublications.org/doi/pdf/10.2105/AJPH. 62.10 .1331

[19] Sedgh, G., Henshaw, S. K., Singh, S., Bankole, A., \& Drescher, J. (2007). Legal abortion worldwide: Incidence and recent trends. Perspectives on Sexual and Reproductive Health, 39(4), 216-225. https://onlinelibrary.wiley.com/doi/abs/10.1363/3921607

[20] Tafheemul Quran Commentary. Islamic Studies. https://www.islamicstudies.info/tafheem.php?sura=2\&ve rse $=229$

[21] Islamic Jurist Council of the Islamic World League. (1991). The 4th resolution on aborting a congenital malformed fetus, Islamic Jurist Council of the Islamic World League, Makkah Al Mukaramah, 12th session 1017th February 1990 and also quoted appendix No 1, in M.Albar: Al Ganin Al Mushawah (The congenitally malformed fetus), Dar Al Qalam Damascus and Dar Al Manara Jeddah. 1991:439. https://books.google.com/books?id=Qqy4CQAAQBAJ\& $\mathrm{p}$

[22] World Health Organization. (2012) Safe abortion: Technical and policy guidance for health systems. World Health Organization. https://www.who.int/reproductivehealth/publications/uns afe_abortion/9789241548434/

[23] Wu, D. D., Belak, J., \& Rozman, M. P. (2012). Business ethics from Aristotle, Kant and Mill's perspective. https://www.emerald.com/insight/content/doi/10.1108/03 684921211276783/full/html

\section{Author Profile}

Alqahtani Jawhrah received a B.S. degree in Nursing from King Saud University in the Kingdom of Saudi Arabia, and received an M.S degree in Nursing Education from Roberts Wesleyan College in the United States of America respectively. Currently, she is completing her $\mathrm{PhD}$ in Nursing at Barry University in the state of Florida, the United States of America. 